\title{
Direct and indirect effects of a macroalgal canopy and limpet grazing in structuring a sheltered inter-tidal community
}

\author{
Stuart R. Jenkins ${ }^{1, *}$, Stephen J. Hawkins ${ }^{2}{ }_{\text {, Trevor A. Norton }}{ }^{1}$ \\ 'Port Erin Marine Laboratory, University of Liverpool, Port Erin IM9 6JA, Isle of Man, UK \\ ${ }^{2}$ Division of Biodiversity and Ecology, University of Southampton, Bassett Crescent East, Southampton SO16 7 PX, \\ England, UK
}

\begin{abstract}
The dominant components of the mid-shore community of 4 sheltered, rocky shores in the south of the Isle of Man, UK, were surveyed. A 2-way factorial experiment to investigate the community structuring roles of Ascophyllum nodosum (hereafter Ascophyllum) canopies and Patella vulgata grazing was undertaken at 1 site and monitored over a period of $6 \mathrm{yr}$. Removal of the canopy had a marked impact on the understorey community, with both direct and indirect effects. In contrast, the effect of limpet removal was limited, owing to the restriction of this grazer to small patches of bare substrate within a turf of red algae. The Ascophyllum canopy directly facilitated the presence of the red algal turf in the mid-shore; canopy removal resulted in bleaching and death of turf species with a consequent loss of entrapped silt. This degradation of the turt resulted in an increase in the area grazed by limpets and a subsequent increase in limpet recruitment, proportional to the increased area of bare substratum. Thus, the Ascophyllum canopy indirectly limits the population of $P$. vulgata by facilitating the growth of a red algal turf. Eighteen months after Ascophyllum removal, a mixed canopy of Fucus vesiculosus and Fucus serratus developed. This acted in a similar manner to the original canopy, providing shade for turf species, which resulted in restoration of the balance between algal turf and limpet grazing. Despite this, the red algal turf had not fully recovered $5 \mathrm{yr}$ after it was originally bleached, illustrating the long-term effects of Ascophylum canopy loss on this community. Removal of the canopy also resulted in high levels of Ascophyllum recruitment, but the slow growth rate of these juvenile plants meant that nearly 6 yr after canopy removal, an Ascophyllum canopy had still not developed Nonetheless, we predict that Ascophyllum will eventually outcompete the established Fucus spp. canopy. Detailed examination of the distribution of Ascophyllum juveniles suggests that the low density of juveniles in the natural population is due to a lack of substratum free from both limpets and space-occupying turf, rather than a direct effect of the canopy.
\end{abstract}

KEY WORDS: Ascophyllum nodosum - Patella vulgata Community structure - Grazing · Indirect effects · Canopy algae

\section{INTRODUCTION}

The role of canopy algae in structuring communities of the intertidal and shallow subtidal zones has been the subject of numerous studies (e.g. Cowen et al. 1982, Reed \& Foster 1984, Santelices \& Ojeda 1984, Duggins \& Dethier 1985, Hawkins \& Harkin 1985, Kennelly 1988, Chapman 1990, Benedetti-Cecchi \& Cinelli

•E-mail: stu@liverpool.ac.uk
1992, McCook \& Chapman 1997). Macroalgal canopies regulate community structure by radically altering the physical environment. Lowering of light levels (Reed \& Foster 1984), physical abrasion by sweeping algal fronds (Velimirov \& Griffiths 1979, Hawkins 1983), amelioration of physical extremes (McCook \& Chapman 1991) and reduction of water movement (Duggins et al. 1990) have all been shown to influence community structure. One area which remains to be investigated in detail is the way in which canopy algae interact with grazers to influence the distribution and 
abundance of understorey species. Duggins \& Dethier (1985) and Jenkins et al. (1999) demonstrated a negative, additive effect of canopy and grazers on understorey algae in low-shore habitats. At higher shore levels the relative importance of canopy and grazers on understorey species in canopy-dominated communities has rarely been investigated (but see Chapman 1989).

In the mid-intertidal zone of NW Europe, Patella vulgata is the dominant grazer and on exposed shores has an extremely important community structuring role regulating the recruitment of algae (see Hawkins et al. 1992 for review). As one moves into shelter, the large macroalgal canopy-forming species Ascophyllum nodosum (hereafter Ascophyllum), which is completely absent on exposed shores, increases in abundance and dominates the mid-shore region. This is accompanied by an increase in cover of turf-forming algae and a decline in density of $P$. vulgata (Lewis 1964). The cause of this decline in limpet density with shelter from wave action has been speculated upon but not experimentally investigated. Lewis \& Bowman (1975) suggested that fucoids act as a barrier to limpet recruitment. Alternatively turfs of understorey algae beneath Ascophyllum may limit the space available for limpet recruitment (Hawkins et al. 1992). At sheltered sites, Ascophyllum forms a near monospecific cover over much of the mid-shore (Lewis 1964, Stephenson \& Stephenson 1972). Because of its commercial importance, a number of studies have investigated the potential of Ascophyllum for regrowth or recolonisation in harvested or experimentally denuded areas (Baardseth 1955, Printz 1956, 1959, Keser et al. 1981. Keser \& Larson 1984, Sharp 1986). However examination of interactions between the canopy, grazers and the understorey has been neglected (but see Burrows 1947, Boaden \& Dring 1980).

The general aim of this study was to determine the effects of the Ascophyllum canopy and grazing by Patella vulgata on the mid-shore community structure of a sheltered rocky site. Ascophyllum was experimentally removed to test the hypothesis that the canopy facilitates the presence of a red algal turf at mid-shore level and in so doing indirectly limits the $P$, vulgata population by limiting the availability of suitable substratum. By simultaneously manipulating $P$. vulgata populations we tested the hypothesis that limpet grazing is not important in structuring mid-shore sheltered communities. We also wished to investigate the recruitment and growth of Ascophyllum following its removal. This very successful canopy alga has an extensive distribution throughout the North A.tantic, but despite a high investment in reproduction (Josselyn \& Mathieson 1978, Aberg 1996) and a high level of successful fertilisation (Baardseth 1970) recruitment of new individuals into mature stands can be surprisingly low (e.g. David 1943). We wished to test the hypothesis that the canopy limits recruitment of juveniles of its own species, and to determine the ability of this alga to recolonise cleared areas over a 6 yr period of study.

\section{METHODS}

Study sites and descriptive sampling. Descriptive sampling of the Ascophyllum zone was undertaken at 4 gently sloping, sheltered shores in the south of the Isle of Man, UK, at Perwick Bay (Site A), at the northern edge of Castletown Bay (Site B) and on the Langness Peninsula (Sites C and D) (Fig. 1). Site $C$ was used for experimental work (see below). The midshore at all 4 sites was dominated by Ascophyllum, which covered a vertical range of between 2.5 and $5 \mathrm{~m}$ above Lowest Astronomical Tide (LAT). At all shores sampled the understorey community can be divided into 2 separate functional units, a multi-species, sediment-trapping red algal turf (see 'Results' for composition) and patches of substratum, kept clear of erect algae by the grazing of Patella vulgata. Observations made during high water using SCUBA and video and during low water showed limpets were permanently restricted to these patches. These 'bare' patches consisted of a mosaic of bare rock and encrusting algae, predominantly Phymatolithon lenormandii, and will subsequently be referred to as 'bare substratum'. The relative proportions of bare substratum and red algal turf and the percentage cover of the Ascophyllum canopy were determined at 3 shore heights within the Ascophyllum zone. In addition, the relationship

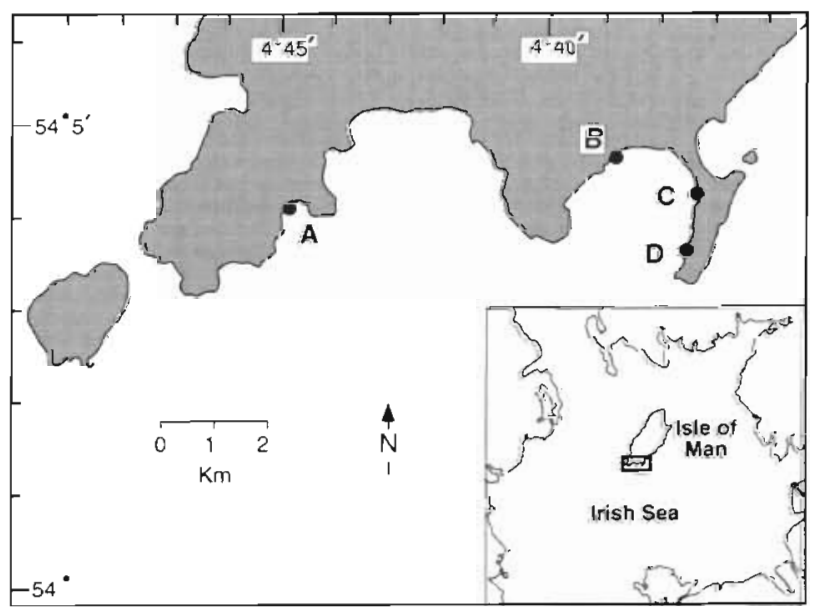

Fig. 1. Location of 4 sheltered sites (A to $D$ ) in the south of the Isle of Man used in August 1994 to describe the distribution of substratum types in the Ascophyllum zone. Inset map shows the position of the Isle of Man in the Irish Sea; the black rectangle depicts the area covered by the main map 
between bare substratum patch size and limpet number was determined along a mid-shore transect on the Langness Peninsula. A total of 68 patches were selected at random and their size estimated using a subdivided quadrat. The shell lengths of all limpets occupying each patch were recorded. A number of other grazers occur in the Ascophyllum zone which were not specifically investigated. Littorina littorea can be abundant on sheltered shores, but was extremely rare in the mid-shore of the sites studied (see Norton et a]. 1990 , for distribution of $L$. Iittorea on the Isle of Man). L. obtusata was abundant on Ascophyllum plants and qualitative observations were made on the distribution and behaviour of this species.

Experimental work. Design and implementation: A 2 -way factorial experiment was designed to investigate the effect of the Ascophyllum canopy and the limpet Patella vulgata on the understorey community. Both factors had 2 levels, presence and absence, resulting in 4 orthogonal treatments which were replicated 3 times.

The experiment was established at Site C (Fig. 1) in the middle of the Ascophyllum zone between 3.3 and $4.3 \mathrm{~m}$ above LAT and covering a horizontal distance of $100 \mathrm{~m}$. Descriptive sampling showed the community structure of the mid-shore of this site was representative of sheltered shores in the south of the Isle of Man. In November 1991 we chose 12 plots all positioned at least $5 \mathrm{~m}$ apart in areas of smooth, gently sloping topography with a dense cover of Ascophyllum. At each plot an area $2 \times 2 \mathrm{~m}$ square was measured and marked at each corner using ring-bolts screwed into holes drilled in the rock. The 4 treatments described above were assigned at random to the 12 plots. In plots which required canopy removal, every individual of Ascophyllum and Fucus serratus over $5 \mathrm{~cm}$ in length was completely removed, including the holdfast. In order that the full $2 \times 2 \mathrm{~m}$ area could be considered free from the influence of the Ascophyllum canopy, individual plants surrounding the plot which could overhang onto its surface were cropped. The exclusion of limpets from experimental plots was simplified because of the concentration of limpets into patches of bare substrate within the red algal turf. This turf acted as a natural barrier to limpet movement thus negating the need for the construction of artificial fences to exclude limpets from experimental plots.

Sampling: Plots were sampled before manipulation and at approximately $6 \mathrm{wk}$ intervals for a period of $2 \mathrm{yr}$ afterwards. Thereafter, sampling was undertaken at irregular intervals over the next $4 \mathrm{yr}$. A $0.5 \times 0.5 \mathrm{~m}$ quadrat, subdivided into 25 equal squares, was placed at 4 random positions within each plot. These 4 subsamples were used to calculate a mean value for each replicate in order to maximise the precision of estima- tion (Hurlbert 1984). In plots where the Ascophyllum canopy was left intact, the percentage cover of canopy algae was first estimated before gently moving it to one side. The percentage cover of understorey algae was estimated and the number of fucoid juveniles recorded. Individual fucoids less than $5 \mathrm{~cm}$ in length, excluding plants that by breakage had decreased in size, were considered to be juveniles. Ascophyllum juveniles grow extremely slowly, with estimates of between $1 \mathrm{~mm}$ (Lazo et al. 1994) and $15 \mathrm{~mm}$ (Baardseth 1970) of growth in the first year. Thus, even accepting greater growth in subsequent years, a $5 \mathrm{~cm}$ long $A$ scophyllum plant may be several years old and so, for Ascophyllum, the term 'juvenile' is used in the sense of size and non-reproductive status rather than age. This classification of 'juveniles' enabled us to follow the density of new Ascophyllum recruits after experimental manipulation over a number of years.

The red algal turf, an association of red algal species and entrapped sediment, was treated as a single functional unit and sampled as such. In addition, the percentage cover of the most conspicuous species, Chondrus crispus, which was common throughout the turf, was estimated. A purely qualitative description was also made at each sampling date of the state of the red algal turf in each treatment.

Patches of bare substrate were examined carefully at each sampling date, and the total number and size of limpets in each patch recorded. The area of each patch was estimated using a quadrat subdivided into 25 squares, measurements being repeated 3 times to ensure accuracy. In the control, an additional method was employed to determine patch size. A sheet of clear polythene was placed over each patch and the boundary between bare substrate and turf traced onto the polythene using a marker pen. The area of each patch was then determined in the laboratory. This not only produced an accurate measure of patch size, but also a permanent record of patch shape which enabled an assessment of the stability of patches in the natural community.

In August 1994 the distribution and density of Ascophyllum juveniles were examined in detail in the 4 treatments. Sampling was divided between turf and patches of bare substrate in order to establish where juveniles were recruiting to. For both substrata, five $0.25 \times 0.25 \mathrm{~m}$ quadrats were positioned at random within each replicate plot, and the number of juveniles counted.

Statistical treatment of data: Analysis of the experiment was performed using a 2-way ANOVA with both factors, canopy and limpet grazing, considered fixed. Heterogeneity of variance was tested for using Cochran's test and, where appropriate, arcsine transformations applied. 


\section{RESULTS}

\section{Patterns in the Ascophyllum zone}

All 4 shores sampled had a near $100 \%$ cover of $A$ scophyllum at all shore levels. Red algal turf was the dominant component of the understorey, its mean percentage cover averaged over the Ascophyllum zone ranging from $62 \%$ at Perwick to $87 \%$ at Castletown. The turf consisted of a number of red algal species, predominantly Chondrus crispus, Gelidium pusillum. G. latifolium, Corallina officinalis plus others such as Laurencia spp., Audouinella floridula and Lomentaria articulata. The thalli of these algae bound a layer of silt which in the undisturbed community ensured that, where present, the turf formed a continuous cover over the rock surface. The remainder of the understorey was made up of patches of bare substratum grazed by Patella vulgata. The cover of bare substratum was significantly greater at the high-shore level (Fig 2, Table 1) although the effect of shore height on the balance between the 2 types of understorey was clearly not consistent between all 4 shores (Fig. 2).

The overall density of Patella vulgata at mid-tide level on the sheltered shores investigated was low in comparison to neighbouring exposed shores (Table 2). However, the sheltered shore limpets are confined to relatively small patches of bare substratum and do not graze on the turf. Density, calculated as number per unit area of grazeable substrate, was thus higher on sheltered compared to exposed shores, since a relatively large number of limpets are concentrated in small areas of bare substratum.

The size of bare substratum patches showed a strong correlation with numbers of limpets inside the patch

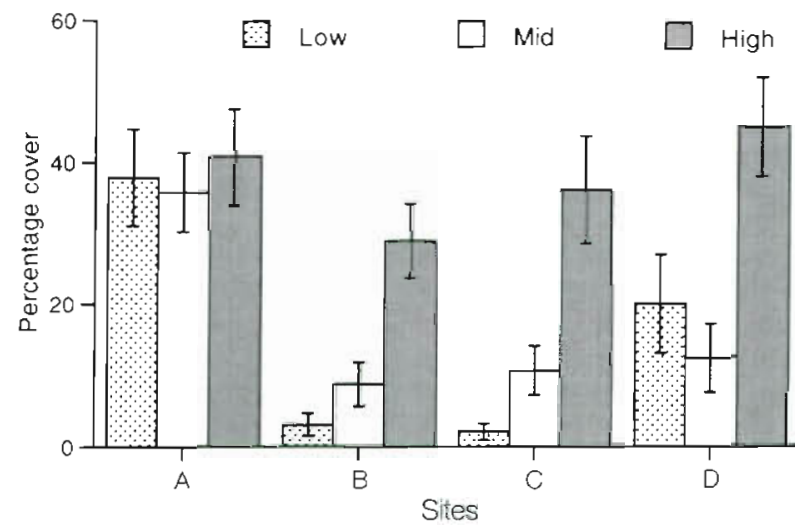

Fig. 2. Percentage cover of bare substratum at 3 tidal heights within the Ascophyllum zone on 4 sheltered shores (A to D) in the south of the Isle of Man. For each height at each shore a $100 \mathrm{~m}$ transect was established parallel to the shoreline. Twenty $0.5 \times 0.5 \mathrm{~m}$ quadrats were placed at random along each transect. Error bars: $\pm 1 \mathrm{SE}$
Table 1. ANOVA of the percentage cover of bare substratum on sheltered shores in the south of the Isle of Man. Shore was treated as a random factor while tidal height was fixed

\begin{tabular}{|lrrrc|}
\hline Source & df & \multicolumn{1}{c}{ MS } & $F$ & $p$ \\
\hline Shore & 3 & 7398.1 & 12.51 & $<0.001$ \\
Tidal height & 2 & 12094.2 & 9.95 & $<0.02$ \\
Shore $\times$ Height & 6 & 1215.8 & 2.06 & $<0.06$ \\
Residual & 228 & 591.4 & & \\
\hline
\end{tabular}

Table 2. Patella vuigata. Mean density \pm 1 SE of individuals over $15 \mathrm{~mm}$ in length at mid-tide level of sheltered and exposed shores on the lsle of Man

\begin{tabular}{|lcc|}
\hline & $\begin{array}{c}\text { Density } \\
\text { (ind. } \mathrm{m}^{-2} \text { ) }\end{array}$ & $\begin{array}{c}\text { Density } \\
\text { (ind. }{ }^{-2} \text { bare space) }\end{array}$ \\
\hline Sheltered & & \\
Perwick & $18.0 \pm 3.1$ & $57.3 \pm 10.1$ \\
Castletown & $8.6 \pm 1.5$ & $51.1 \pm 14.2$ \\
Langness (inner) & $7.4 \pm 1.8$ & $67.0 \pm 7.1$ \\
Langness (outer) & $7.1 \pm 1.3$ & $50.9 \pm 8.6$ \\
Exposed & & \\
Port St. Mary & $22.2 \pm 2.1$ & $23.3 \pm 2.3$ \\
Derbyhaven & $29.4 \pm 2.5$ & $29.8 \pm 2.5$ \\
Scarlett & $34.8 \pm 2.4$ & $35.2 \pm 2.5$ \\
Niarbyl & $38.4 \pm 2.7$ & $41.9 \pm 3.1$ \\
& & \\
\hline
\end{tabular}

$(\mathrm{r}=0.838, \mathrm{p}<0.01 ;$ Fig. 3 ). This correlation was not improved by substituting limpet biomass (measured as soft tissue dry weight) for limpet number ( $r=0.824$, $p<$ 0.01 ). Biomass of limpets in each patch was calculated using a regression of limpet length on soft tissue dry weight from limpets obtained within the Ascophyllum zone of 2 sheltered shores on the Isle of Man (unpubl. data).

\section{Canopy and grazer manipulation}

\section{Ephemeral green algae}

The cover of ephemeral green algae was very low $(<4 \%)$ throughout the experimental period in plots where the canopy was intact, irrespective of the presence or absence of limpets (Fig. 4). Removal of the Ascophyllum canopy had a pronounced effect on the cover of ephemerals, with blooms in the spring and summer of 1992 and to a lesser extent 1993. The effect of canopy removal was highly significant in the first year following establishment of the experiment (July 1992, Table 3). In the second year (1993) the effect of canopy removal was greater where limpets were also removed (significant interaction term, Table 3). This is consistent with field observations which showed that 
limpet grazing prevented recruitment of ephemerals to bare substrate, thereby restricting colonisation to the turf.

Fucus spp. canopy cover

Removal of Ascophyllum resulted in the development of a mixed canopy of Fucus serratus and $F$. vesiculosus (Fig. 4). In control plots, $F$. vesiculosus was completely absent whilst $F$. serratus occurred in small

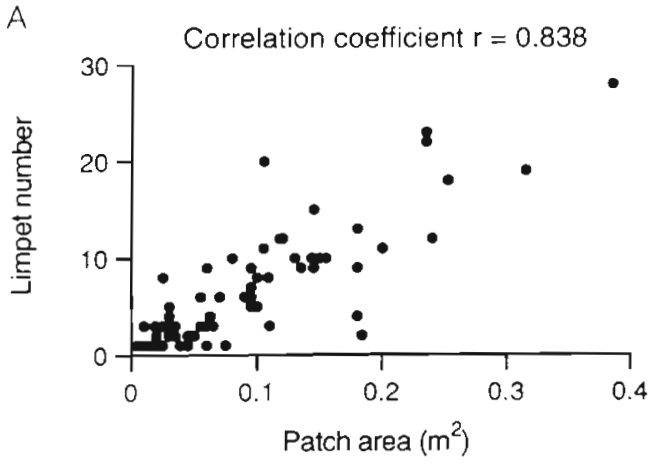

amounts $(<10 \%$ cover). For both species there was no effect of limpets but a significant effect of Ascophyllum removal (Table 3). A mixed Fucus spp. canopy was persisting in experimental plots nearly 6 yr after the start of the experiment.

\section{Ascophyllum recruitment}

Removal of the Ascophyllum canopy resulted in a dramatic change in the density of Ascophyllum

B

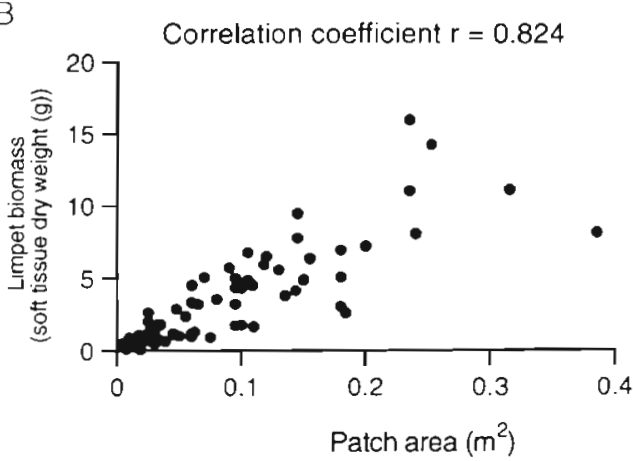

Fig. 3. Patella vulgata. Relationship between size of bare substrate patch sizes and (A) limpet number, (B) limpet biomass measured as soft tissue dry weight
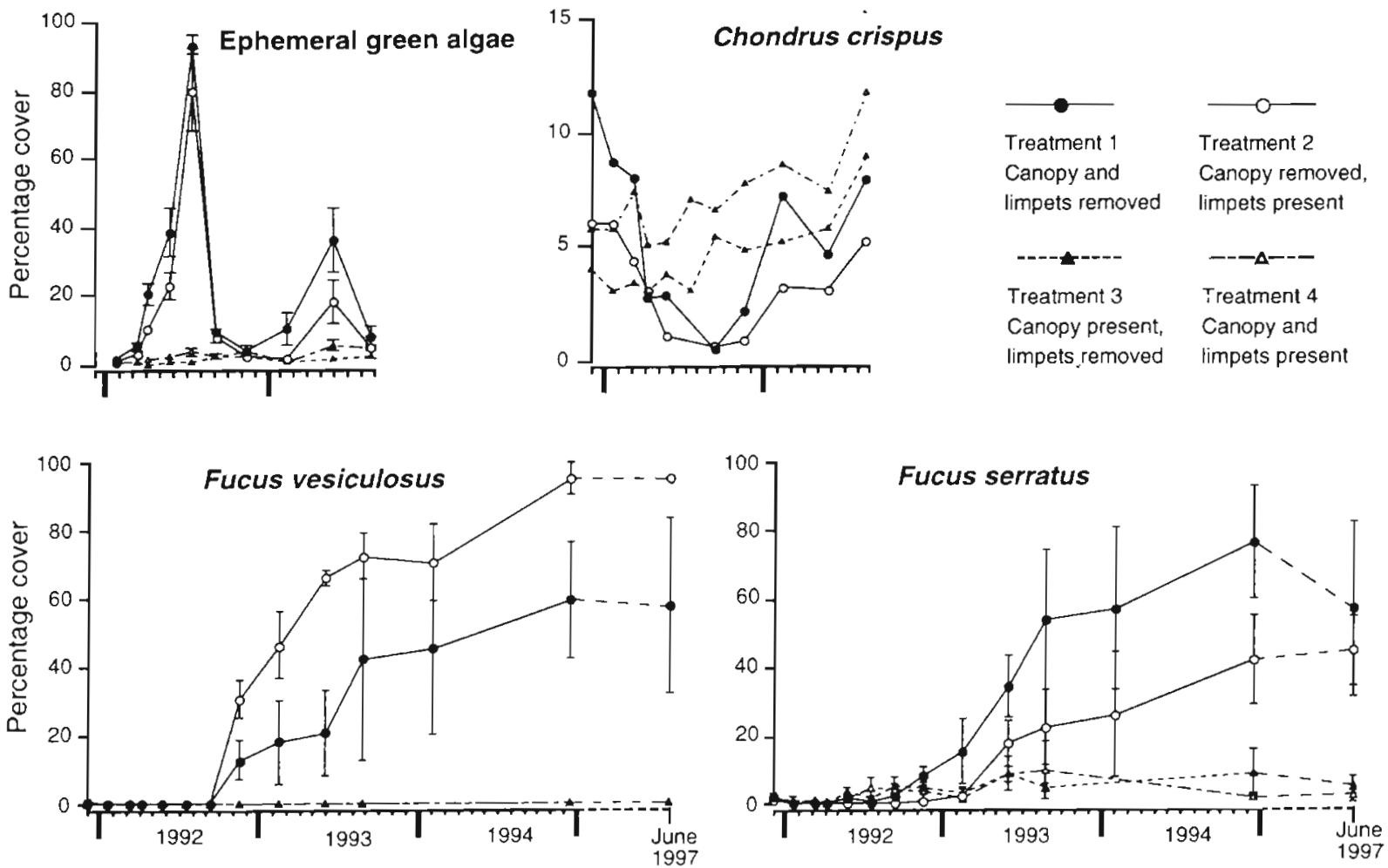

Fig. 4. Mean percentage cover of algal species in experimental plots. Error bars: \pm 1 SE. For Chondrus crispus: note different vertical scale. Also, SE estimates overlap considerably and have been omitted for clarity 
Table 3. ANOVA on the abundance of algae in experimental plots. All data are arcsine transformed following Cochrans's test, except for Ascophyllum juveniles

\begin{tabular}{|c|c|c|c|c|c|c|c|}
\hline & df & MS & $F$ & $\mathrm{p}$ & MS & $F$ & $\mathrm{p}$ \\
\hline & & \multicolumn{3}{|c|}{$\begin{array}{l}\text { Fucus serratus } \\
\text { December } 1994\end{array}$} & \multicolumn{3}{|c|}{$\begin{array}{l}\text { Fucus vesiculosus } \\
\text { December } 1994\end{array}$} \\
\hline Canopy & 1 & 4700.36 & 19.51 & $<0.004$ & 11461.15 & 77.46 & $<0.0001$ \\
\hline Limpet & 1 & 618.59 & 2.57 & $>0.15$ & 532.86 & 3.64 & $<0.1$ \\
\hline Canopy $\times$ Limpet & 1 & 225.18 & 0.93 & $>0.35$ & 532.86 & 3.61 & $<0.1$ \\
\hline \multirow[t]{2}{*}{ Residual } & 7 & 240.98 & & & 147.96 & & \\
\hline & & \multicolumn{3}{|c|}{$\begin{array}{l}\text { Ephemeral green algae } \\
\text { July } 1992\end{array}$} & \multicolumn{3}{|c|}{$\begin{array}{c}\text { Ephemeral green algae } \\
\text { May } 1993\end{array}$} \\
\hline Canopy & 1 & 12103.99 & 109.00 & $<0.0001$ & 1314.05 & 28.98 & $<0.0007$ \\
\hline Limpet & 1 & 12.73 & 0.11 & $>0.7$ & 21.19 & 0.47 & $>0.5$ \\
\hline Canopy $\times$ Limpet & 1 & 131.68 & 1.18 & $>0.3$ & 276.24 & 6.09 & $<0.04$ \\
\hline \multirow[t]{2}{*}{ Residual } & 8 & 111.37 & & & 45.35 & & \\
\hline & & \multicolumn{3}{|c|}{$\begin{array}{l}\text { Ascophyllum juveniles } \\
\text { November } 1994\end{array}$} & \multicolumn{3}{|c|}{$\begin{array}{l}\text { Chondrus crispus } \\
\text { September } 1992\end{array}$} \\
\hline Canopy & 1 & 206063.06 & 4.28 & $<0.08$ & 294.14 & 41.53 & $<0.0002$ \\
\hline Limpet & 1 & 5963.01 & 0.12 & $>0.7$ & 2.18 & 0.31 & $>0.59$ \\
\hline Canopy $\times$ Limpet & 1 & 38250.54 & 0.79 & $>0.35$ & 0.25 & 0.04 & $>0.85$ \\
\hline Residual & 8 & 48080.52 & & & 7.08 & & \\
\hline
\end{tabular}

juveniles which was first observed in September 1992, 10 mo after experimental manipulation (Fig. 5). A steady rise in density occurred over a period of 3 yr in both treatments in which the canopy was removed, although a high degree of spatial variation in the distribution of juveniles occurred both within and between replicates. In December 1994, 3 yr after the start of the experiment, maximum mean densities in the canopy removal treatments with and without limpets were 378 and $221 \mathrm{~m}^{-2}$ respectively. These densities compare with a mean background level in control plots of less than 6 juveniles $\mathrm{m}^{-2}$. Despite the high mean density in canopy removal treatments, large spatial variability ensured the effect of canopy removal was not significant at the $5 \%$ level $(p<0.07$, Table 3$)$.

A more rigorous investigation of the distribution of Ascophyllum juveniles in August 1994 revealed distinct differences in the effects of the 2 factors, canopy and limpet grazing, depending on the substrate type (turf or bare substratum). ANOVA using substrate type as a factor was not possible owing to the lack of independence between samples; estimates of juvenile density for the 2 different substrate types were made in the same experimental plots. Therefore separate analyses were performed for each substrate type. There was a significant effect of limpet removal on the density of Ascophyllum juveniles on bare substrate. Densities were high on bare substrate where limpets were removed, irrespective of the presence of the Ascophyllum canopy (Fig. 6, Table 4). In contrast, removal of limpets had no effect on the density of Ascophyllum juveniles growing amongst the turf. High levels of Ascophyllum juveniles occurred only in plots cleared of canopy. The effect of canopy removal on juvenile density amongst the turf was just insignificant at the $5 \%$ level $(\mathrm{p}<0.06$, Table 4$)$.

Sampling in June 1997 showed that the increase in abundance of Ascophyllum juveniles had ceased at some point after the end of 1994. Juvenile density had

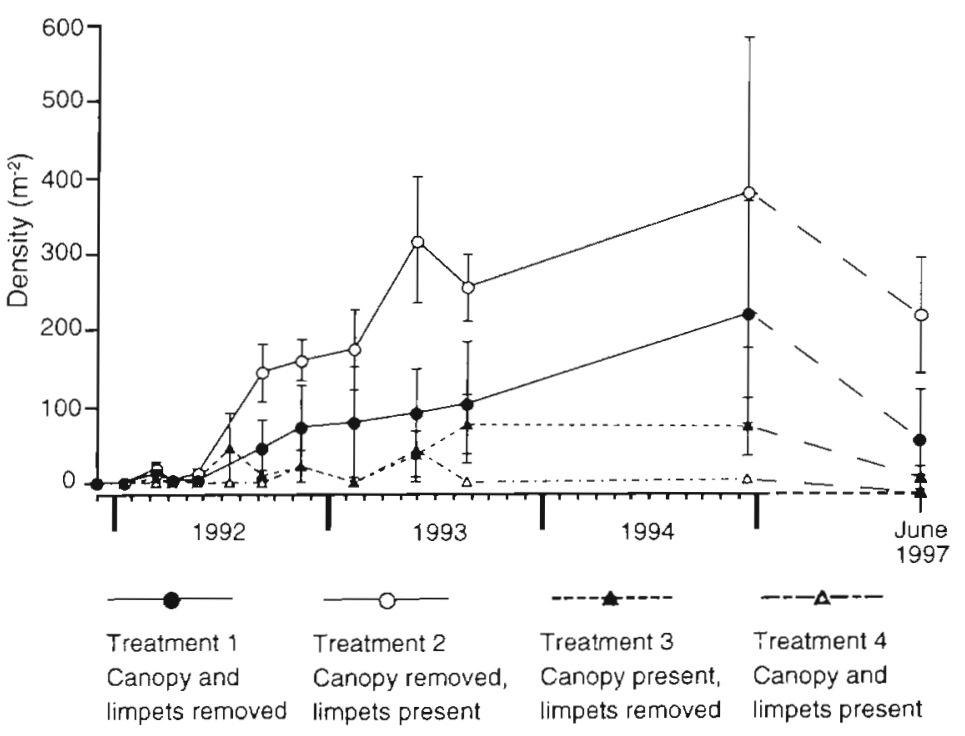

Fig. 5. Ascophyllum nodosum. Mean density of juveniles $(<5 \mathrm{~cm}$ in length) in experimental plots. Error bars: $\pm 1 \mathrm{SE}$ 

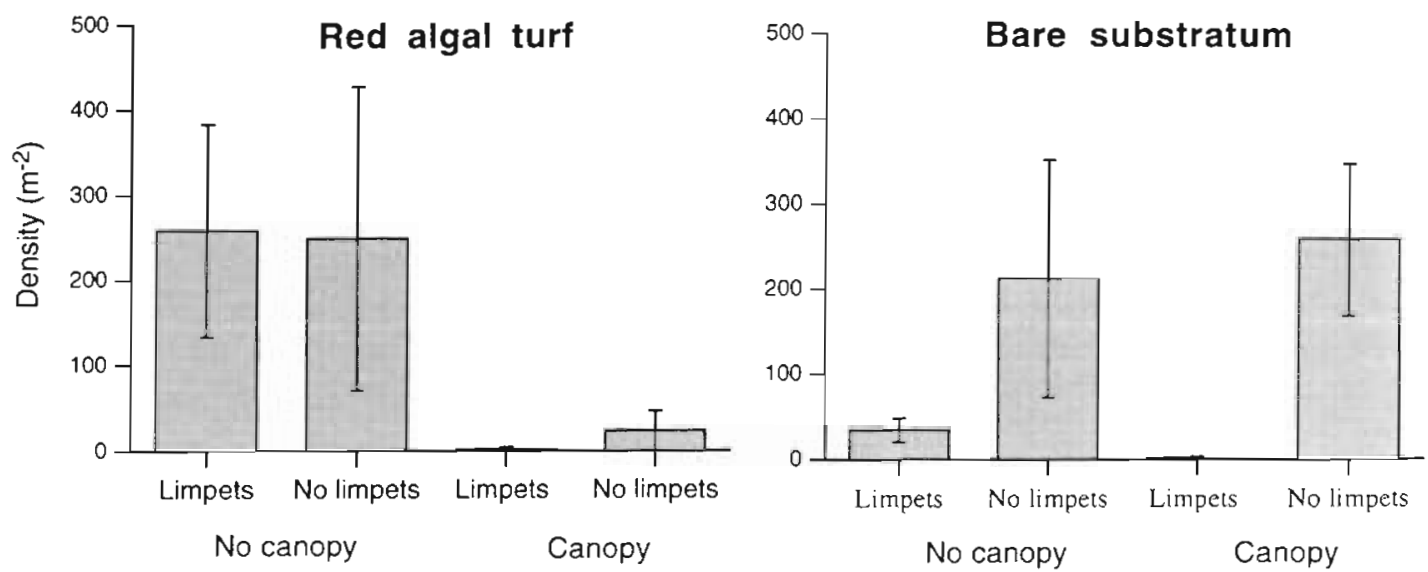

Fig. 6. Ascophyllum nodosum. Distribution of juveniles in August 1994 on red algal turf and bare substrate in experimental plots Error bars: $\pm 1 \mathrm{SE}$

decreased in all treatments (Fig. 5). Analysis of the size distribution of the Ascophyllum plants at this time, in plots where the canopy had been removed, showed that the number of new recruits ( $<1 \mathrm{~cm}$ in length) was minimal, suggesting that the conditions which allowed such high recruitment at the start of the experiment no longer existed. The dominant size class in June 1997 (5 yr after high recruitment levels had first been observed) was between 3 and $5 \mathrm{~cm}$ with all but 1 individual ( $42 \mathrm{~cm}$ in length) out of 200 measured being less than $20 \mathrm{~cm}$ in length.

\section{Red algal turf}

Qualitative observations showed distinct changes in the red algal turf following removal of the canopy. Bleaching was apparent in red algae as early as January (2 mo after canopy removal), leading to severe die back of the turf species over the next few months. Colonisation of the bleached turf by ephemeral algae in the spring and summer resulted in considerable silt accumulation. However, as ephemeral cover declined through late summer and autumn this silt was lost, especially from areas where red algae had died. This led to the opening up of large areas of bare rock. Recovery of red algae from bleaching began in
November 1992 with regrowth of Gelidium species especially beneath the new canopy of Fucus spp. This trend of recovery and regrowth continued throughout the spring and summer of 1993 where the turf was protected by new canopy. However, where the canopy was absent the turf remained stunted and patchy.

The qualitative description of changes in the red algal turf is reinforced by examining changes in cover of Chondrus crispus in experimental plots. Cover of this common component of the turf had significantly reduced in canopy removal plots by September 1992 (Table 3, Fig. 4). This was followed by an increase in cover as a new fucoid canopy developed.

Sampling of the turf in August 1994 and June 1997 revealed that although regrowth of red algae had occurred, the results of turf degradation due to canopy removal were persistent. The percentage of rock visible within the turf matrix was significantly higher in plots cleared of canopy in both 1994 (1-way ANOVA: $\left.F_{(1,10)}=27.19, \mathrm{p}<0.0004\right)$ and 1997 (1-way ANOVA: $\left.F_{(1.10)}=15.25, \mathrm{p}<0.003\right)($ Fig. 7$)$

\section{Patch sizes}

The area of selected patches of bare substrate in experimental plots showed distinct changes in size as a

Table 4. Ascophyllum nodosum. ANOVA of the density of juveniles on 2 different substrata in August 1994

\begin{tabular}{lcrrrrrr} 
& df & \multicolumn{2}{c}{ Turf } & \multicolumn{2}{c}{ Bare substrate } \\
& & MS & $F$ & $p$ & MS & $F$ \\
\hline Canopy & 1 & 174.170 .71 & 4.84 & $<0.06$ & 128.58 & 0.01 & $>0.9$ \\
Limpet & 1 & 94.64 & 0.00 & $>0.9$ & 141110.80 & 8.46 & $<0.02$ \\
Canopy $\times$ Limpet & 1 & 709.94 & 0.02 & $>0.8$ & 4669.70 & 0.28 & $>0.6$ \\
Residual & 8 & 35968.86 & & & 16690.06 & \\
\hline
\end{tabular}




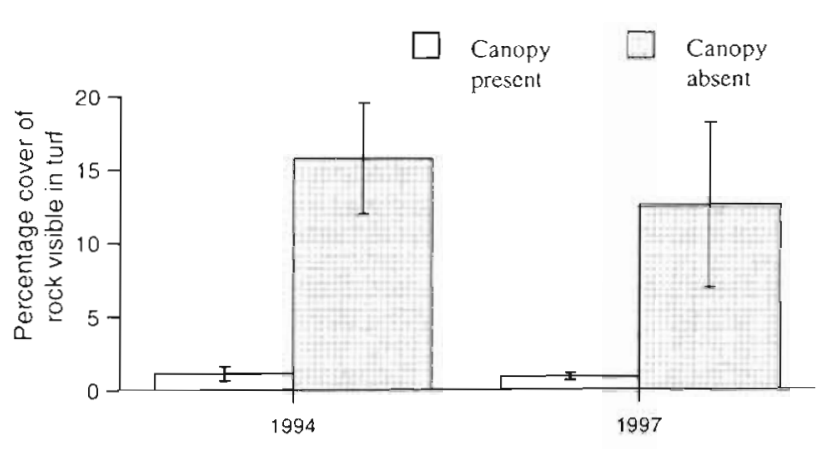

Fig. 7. Mean percentage cover of bare rock visible within the turf matrix in August 1994 and June 1997. Treatments where limpets were present and absent were pooled within each of the canopy treatments. Error bars: $\pm 1 \mathrm{SE}$

result of canopy and limpet manipulation. In control plots, where no manipulation had taken place, individual patches showed small variations in size and shape although there was no overall change in area over $2 \mathrm{yr}$. Removal of limpets alone (Treatment 3) resulted in a distinct reduction in patch size to $46 \%$ of their original area after 2 yr, due to overgrowth by red aigae (Fig. 8). In Treatment 1 , where both canopy and limpets were removed, patch size appeared to be governed largely by growth of ephemerals, with complete overgrowth of bare substrate in the spring and summer of 1992 and 1993. Between blooms of ephemerals, the mean patch size increased to $153 \%$ of the original size owing to degradation of the algal turf. Removal of only the canopy, leaving limpets undisturbed (Treatment 2), caused a gradual increase in patch area over a period

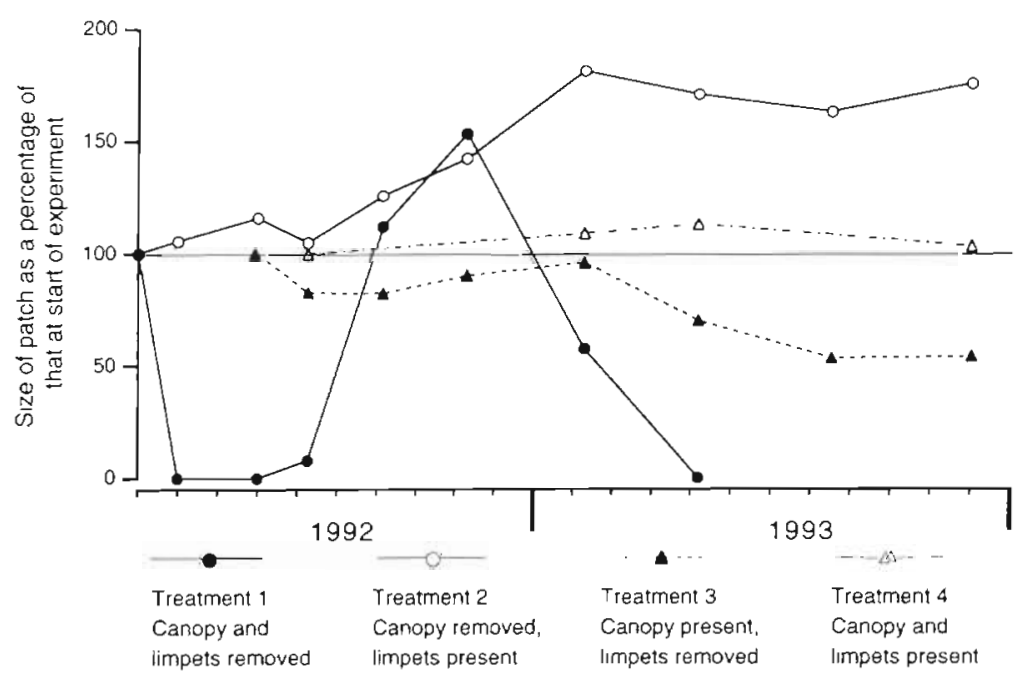

Fig. 8. Size of bare substrate patches in experimental plots calculated as a percentage of the size at the beginning of the experiment. Individual patches within each experimental plot summed, and mean of 3 plots for each treatment calculated. Sampling of Treatment 3 was stopped after May 1993 owing to loss of distinct patch boundaries of 1 yr to a peak of $181 \%$ of their original size. Stabilisation of patch area following this was probably caused by development of Fucus spp. canopies allowing turf-forming algae to recover.

\section{Limpet recruitment}

Observations over a 2 yr period (1992 to 1993) showed the recruitment of limpets to patches of bare substratum, calculated as number of new recruits per unit area of bare substratum, was the same in the presence and absence of the Ascophyllum canopy (Fig. 9A). However, in plots where the canopy was removed the area of bare substratum nearly doubled in size, resulting in significantly higher recruitment per unit area of shore in 1993 (Fig. 9B; $F_{(1.6)}=6.43, \mathrm{p}<0.05$ ) and a just insignificant result in $1994\left(F_{(1.6)}=4.67, \mathrm{p}<0.10\right)$.

\section{DISCUSSION}

\section{Interactions between the Ascophyllum canopy, red algal turi and Patella vulgata}

Our work suggests that limpets play a very limited role in structuring the mid-shore community of sheltered shores. This is in sharp contrast to the situation on more exposed shores of NW Europe, where the ability of limpets to limit algal recruitment means they are the dominant structuring organism (Southward 1964, Southward \& Southward 1978, Hawkins 1981, see Hawkins et al. 1992 for review). On the sheltered shore studied, Ascophyllum indirectly limits the grazing range of limpets by facilitating the growth and spatial dominance of the red algal turf. In so doing the influence of limpets on the understorey community is limited to a restricted area.

Turf-forming species of algae tend to be limited to the low-shore or the subtidal zone world-wide (Stephenson \& Stephenson 1972, Kain \& Norton 1990). However, many species of algae extend further upshore when protected from desiccation by overlying large algae (Lewis 1964. Hawkins \& Hartnoll 1985). Experimental removal of the Ascophyllum canopy resulted in bleaching and consequent degradation of the red algal turf, allowing expansion of the grazing range of limpets. Interestingly, bleaching occurred even in the winter, suggesting that the canopy has an ameliorating effect throughout the year. The expansion of the grazing range of limpets stopped approximately 1 yr 

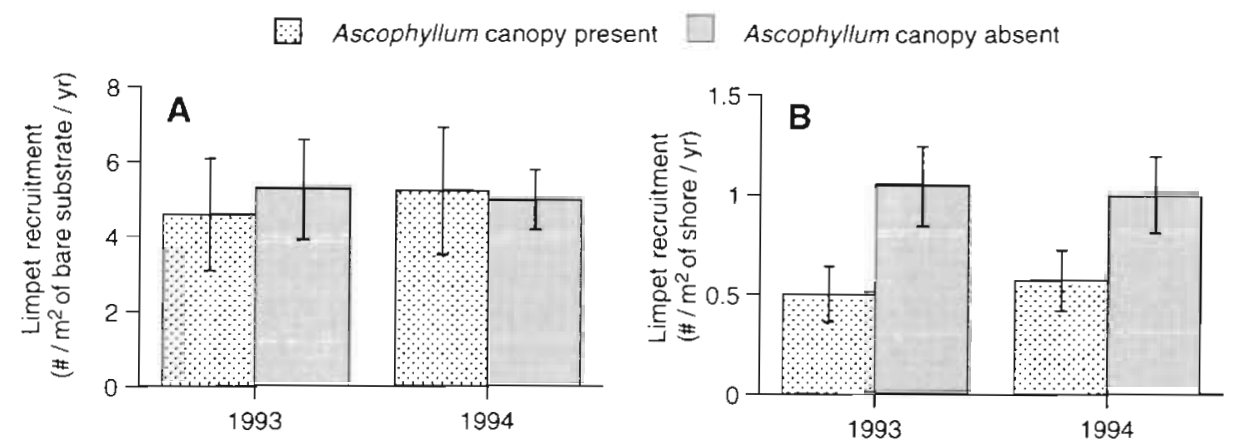

Fig. 9. Patella vulgata. Recruitment of individual limpets to bare substratum patches. Number of new recruits in each year counted and recruitment expressed as (A) number of recruits per square metre of bare substratum and (B) number of recruits per square metre of the mid-shore. A value of $11 \%$ bare substrate cover at mid-shore level of the experimental site in the undisturbed community was used to calculate recruitment per unit area of shore. Error bars: $\pm 1 \mathrm{SE}$

after canopy removal, coinciding with the development of a new fucoid canopy, a mixed stand of Fucus serratus and $F$. vesiculosus. It seems likely this canopy acted in a similar way to the original Ascophyllum plants, providing shade for the turf species and thus limiting the damaging effects of prolonged emersion. Regrowth of the turf species did occur under the new canopy, although the turf had not fully recovered nearly 6 yr after establishment of the experiment, thus illustrating the longterm effects of canopy removal in this community.

In the undisturbed community, there was a balance between the areas of bare substrate and of turf. Limpet grazing prevented vegetative expansion of red algae, but equally the red algal turf prevented limpets from expanding their grazing range. This balance was mediated by the presence of a canopy. It may appear incongruous that limpets, which so effectively regulate the biomass of algae on exposed shores, can in turn be regulated by algal growth. However, Patella vulgata exerts its effect on exposed shores by grazing on the epilithic microbial film (Hill \& Hawkins 1990) and rarely feeds on mature stages of macroalgae. Thus limpets can be excluded from habitats by algal growth either by pre-emption of space (Dye 1993) or by the physical swamping of limpets by fast-growing algae low on the shore (Underwood \& Jemakoff 1981, Hawkins \& Harkin 1985).

The facilitation of growth of the red algal turf by the Ascophyllum canopy not only limits the range of limpet grazing, but it may also seriously affect recruitment of limpets to the shore. Limpet larvae are thought to settle preferentially in pools lined with calcified red algae (Bowman 1981, Morse 1991). We think it unlikely that larvae will settle and survive on the turf (see Lewis \& Bowman 1975), and so recruitment will be limited to patches of bare substrate. Following canopy removal, limpet recruitment to experimental plots increased in direct proportion to the subsequent increase in area of bare substratum. Thus, by facilitating the presence of the turf, the Ascophyllum canopy indirectly limits limpet recruitment to the mid-shore of sheltered sites by restricting the total free space available for settlement. This study therefore provides evidence for a potential cause of the decline in limpet abundance across the wave exposure gradient on shores of NW Europe, from exposed shores where limpets have an important role in regulating macroalgal cover (see Hawkins et al. 1992 for review) to sheltered localities where limpet density is low. This indirect control of limpet abundance is likely to have a significant effect on understorey community structure. However, given the long-lived nature of Ascophyllum and low reliance on sexual reproduction, it seems unlikely that a greater abundance of limpets would have a significant effect on the ability of this fucoid alga to dominate the midshore of sheltered sites.

The importance of indirect effects in rocky intertidal habitats was recently assessed by Menge (1995), who concluded that such effects accounted for approximately $40 \%$ of the change in community structure resulting from experimental manipulation. The main indirect effect revealed by our work (a basal species, Ascophyllum, provided shelter for other basal species, red algae, which then had a negative effect on a herbivore, Patella vulgata, through inhibition of feeding and recruitment) was not included in a total of 83 subtypes of indirect effect recognised by Menge from a review of 23 experimentally based studies. This may indicate that this type of interaction is rare, but more likely simply demonstrates the large range of indirect effects in rocky intertidal habitats.

The dominant community-structuring role of the Ascophyllum canopy is demonstrated not only in its facilitation of the red algal turf and the indirect inhibition of limpet populations but also by the direct exclusion from the mid-shore of green ephemeral algae and 
of the canopy fucoids Fucus vesiculosus and F. serratus. In undisturbed communities of Ascophyllum on Manx sheltered shores, $F$. vesiculosus is almost completely absent, whilst $F$. serratus forms a limited subcanopy in the mid and low parts of the Ascophyllum zone (unpubl. obs.). Our results and a number of earlier studies (Knight \& Parke 1950, Boaden \& Dring 1980, Keser et al. 1981, Keser \& Larson 1984) show that both F. serratus and F. vesiculosus are capable of rapid colonisation in the mid-shore of sheltered sites in the absence of Ascophyllum. That they are absent or rare shows the competitive ability of Ascophyllum and the lack of disturbance events which could disrupt the continuous cover of Ascophyllum.

\section{Recruitment and growth of Ascophyllum}

Despite the dominance of Ascophyllum on the midshore of sheltered sites in NW Europe (Lewis 1964), numerous studies have recorded a surprisingly low abundance of juveniles of this species (Oltmanns 1889 , David 1943, Knight \& Parke 1950, Printz 1956, Baardseth 1970, Sundene 1973, Lazo et al. 1994). Detailed observations by Aberg \& Pavia (1997), at a range of spatial scales on the Isle of Man and in Sweden, revealed densities higher than previously reported, with a mean of 40 juveniles $\mathrm{m}^{-2}(<1 \mathrm{~cm}$ in length). However, juveniles were extremely patchily distributed, with a large proportion ( $>75 \%$ ) of the replicated sampling areas $(0.25 \times 0.25 \mathrm{~m})$ containing no juveniles at all

Removal of the Ascophyllum canopy in this study resulted in high levels of recruitment by Ascophyllum juveniles, supporting the hypothesis that the canopy is responsible for limiting the density of juveniles in mature stands. Similar enhancement of recruitment was described by Keser et al. (1981) and Keser \& Larson (1984) working in Maine, northeastern USA. In contrast, other studies carried out in Europe found only low levels of Ascophyllum recruitment following canopy removal (e.g. Knight \& Parke 1950). It is a common observation in experimental studies that canopy algae inhibit recruitment of juveniles of the same species (Lubchenco 1986, Chapman 1989, 1990, Benedetti-Cecchi \& Cinelli 1992). The mechanisms of inhibition have rarely been examined in detail but most studies attribute enhanced juvenile recruitment following canopy removal to increased irradiance (e.g Ambrose \& Nelson 1982, Santelices \& Ojeda 1984, Robertson 1987)

It is tempting to conclude that the Ascophyllum canopy directly limits recruitment probably by a reduction of light levels. However, detailed observations of the distribution of Ascophyllum juveniles be- tween different substrata in the different treatments suggest an alternative hypothesis. Levels of recruitment equivalent to those following canopy removal were found beneath the undisturbed canopy on bare substratum when limpets were removed. Thus, on a substratum free from an occupying cover of turfing algae and limpet grazing, high levels of recruitment can occur despite the presence of an overlying canopy. This suggests that the limiting factor in an undisturbed Ascophyllum community in preventing high recruitment is the lack of substratum free from both turfforming algae and a high density of grazers.

Algal turfs have been shown to inhibit the recruitment of canopy algae, both in the intertidal and subtidal zones (Sousa et al. 1981, Deysher \& Norton 1982, Kennelly 1987, Benedetti-Cecchi \& Cinelli 1992, Worm \& Chapman 1998). The means by which inhibition occurs is unclear, since initial settlement of zygotes in turfs may be higher than on surrounding bare rock (Benedetti-Cecchi \& Cinelli 1992, Worm \& Chapman 1996). However, high post-settlement mortality due to competition for light or nutrients is probably of importance (Reed \& Foster 1984, Kennelly 1987, Worm \& Chapman 1996). Alternatively Ascophyllum zygotes may simply need a firm stable substratum on which to develop. Stewart (1982) observed that entrapped sediment within a turf can deprive spatial competitors of a firm substrate for attachment. This suggests an alternative hypothesis as to the mechanism by which canopy removal causes enhanced recruitment. Canopy removal resulted in turf degeneration and silt loss which led to the generation of a fine-scale mosaic of algae, silt and bare rock. This may promote recruitment by allowing direct settlement of zygotes onto a suitable stable substratum which is not grazed by limpets. Thus, the facilitation of an understorey turf by Ascophyllum may indirectly limit recruitment of its own juveniles.

Grazers other than limpets, such as Littorina littorea (Keser et al. 1981, Cervin \& Aberg 1997) and crustacean mesoherbivores (Cervin \& Aberg 1997), may limit Ascophyllum recruitment. Although locally abundant on the Isle of Man (Norton et al. 1990), L. littorea was virtually absent from our study site. The only common littorinid in the Ascophyllum zone was L. obtusata which generally lives and feeds on the Ascophyllum canopy rather than on the substratum (Williams 1990). The possibility that a reduction in the density of crustacean mesoherbivores following canopy removal may have allowed Ascophyllum recruitment cannot be discounted.

Although recruitment of juveniles was markedly enhanced following canopy removal, the vast majority of recruits had failed to grow beyond $10 \mathrm{~cm}$ in length nearly 6 yr after initiation of the experiment, and plots 
were dominated by Fucus spp. Lack of Ascophyllum canopy recovery is clearly a function of slow growth rate rather than an inability to recruit. Given the continued high density of Ascophyllum plants in canopy removal plots and the ability of Ascophyllum to grow whilst shaded by Fucus spp. canopies (see Keser \& Larson 1984), it seems likely that Ascophyllum will eventually regain dominance.

\section{Summary}

This work shows Ascophyllum nodosum clearly has a very important role in structuring the mid-shore community of sheltered sites. As well as directly limiting the abundance of Fucus species and ephemeral algae, our work provides evidence that this macroalgal canopy indirectly limits the abundance of the dominant intertidal grazer Patella vulgata through its facilitation of a turf community. The role of this grazer is therefore limited at mid-tide level of sheltered sites in contrast to its important role in regulating macroalgal cover at exposed shores.

Acknowledgements. This study was funded by a studentship from the Natural Environment Research Council as part of a PhD thesis carried out at the University of Liverpool's Port Erin Marine Laboratory. Additional funding for long-term experimental. work and data analysis was provided by the Mast III project Eurorock MAS3-CT95-0012

\section{LITERATURE CITED}

Aberg P (1996) Patterns of reproductive effort in the brown alga Ascophyllum nodosum. Mar Ecol Prog Ser 138:199-207

Aberg P, Pavia $H$ (1997) Temporal and multiple scale variation in juvenile and adult abundance of the brown alga Ascophyllum nodosum. Mar Ecol Prog Ser 158:111-119

Ambrose RF, Nelson BV (1982) Inhibition of giant kelp recruitment by an introduced brown alga. Bot Mar 25 265-267

Baardseth E (1955) Regrowth of Ascophyllum nodosum after harvesting. Inst Indus Res Adm Standards, Dublin

Baardseth E (1970) Synopsis of biological data on knobbed wrack Ascophyllum nodosum (L.) Le Jolis. FAO Fish Bio Synop 38:Rev 1

Benedetti-Cecchi L, Cinelli F (1992) Effects of canopy cover, herbivores and substratum type on patterns of Cystoseira spp. settlement and recruitment in littoral rockpools. Mar Ecol Prog Ser 90:183-191

Boaden PJS, Dring MJ (1980) A quantitative evaluation of the effects of Ascophyllum harvesting on the littoral ecosys. tem. Helgol Meeresunters 33:700-710

Bowman RS (1981) The morphology of Patella spp. juveniles in Britain and some phylogenetic inferences. $J$ Mar Biol Assoc UK 61:647-666

Burrows EM (1947) A biological investigation of the behavjour of Ascophyllum nodosum over a period of years and an inquiry into its relations with other components of the algal flora. PhD thesis, London University
Cervin G, Aberg P (1997) Do littorinids affect the survival of Ascophyllum nodosum germlings? J Exp Mar Biol Ecol 218:35-47

Chapman ARO (1989) Abundance of Fucus spiralis and ephemeral seaweeds in a high eulittoral zone: effects of grazers, canopy and substratum type. Mar Biol 102: $565-572$

Chapman ARO (1990) Effects of grazing, canopy cover and substratum type on the abundances of common species of seaweeds inhabiting littoral fringe tide pools. Bot Mar 33: 319-326

Cowen RK, Agegian CR, Foster MS (1982) The maintenance of community structure in a central California giant kelp forest. J Exp Mar Biol Ecol 64:189-201

David HM (1943) Studies in the autecology of Ascophylum nodosum Le Jol. J Ecol 31:178-198

Deysher L, Norton TA (1982) Dispersal and colonisation in Sargassum muticum (Yendo) Fensholt. J Exp Mar Biol Ecol 56:179-195

Duggins DO, Dethier MN (1985) Experimental studies of herbivory and algal competition in a low intertidal habitat. Oecologia 67:183-191

Duggins DO, Eckman JE, Sewell AT (1990) Ecology of understorey kelp environments. 2. Effects of kelps on recruitment of benthic invertebrates. J Exp Mar Biol Ecol 143: $27-45$

Dye AH (1993) Recolonization of intertidal macroalgae in relation to gap size and molluscan herbivory on a rocky shore on the east coast of southern Africa. Mar Ecol Prog Ser 95:263-271

Hawkins SJ (1981) The influence of Patella grazing on the fucoid-barnacle mosaic on moderately exposed rocky shores. Kiel Meeresforsch 5:537-543

Hawkins SJ (1983) Interaction of Patella and macroalgae with settling Semibalanus balanoides (L.). J Exp Mar Biol Ecol $71: 55-72$

Hawkins SJ, Harkin E (1985) Preliminary canopy removal experiments in algal dominated communities low on the shore and in the shallow subtidal on the Isle of Man. Bot Mar 28:223-230

Hawkins SJ, Hartnoll RG (1985) Factors determining the upper limits of intertidal canopy-forming algae. Mar Ecol Prog Ser 20:265-271

Hawkins SJ, Hartnoll RG, Kain JM, Norton TA (1992) Plantanimal interactions on hard substrata in the north-east Atlantic. In: John DM, Hawkins SJ, Price JH (eds) Plantanimal interactions in the marine benthos. Clarendon Press, Oxford, p 1-32

Hill AS, Hawkins SJ (1990) An investigation of methods for sampling microbial films on rocky shores. J Mar Biol Assoc UK 70:77-88

Hurlbert SM (1984) Pseudoreplication and the design of ecological field experiments. Ecol Monogr 54:187-211

Jenkins SR, Hawkins SJ, Norton TA (1999) Interaction between a fucoid canopy and limpet grazing in structuring a low shore intertidal community. J Exp Mar Biol Ecol 233: $41-63$

Josselyn MN, Mathieson AC (1978) Contribution of receptacles from the fucoid Ascophyllum nodosum to the detrital pool of a north temperate estuary. Estuaries 1:258-261

Kain JM, Norton TA (1990) Marine ecology. In: Cole KM, Sheath R (eds) The biology of red algae. Cambridge University Press, Cambridge, p 377-422

Kennelly SJ (1987) Inhibition of kelp recruitment by turfing algae and consequences for an Australian kelp community. J Exp Mar Biol Ecol 112:49-60

Kennelly SJ (1988) Effects of kelp canopies on understorey 
species due to shade and scour. Mar Ecol Prog Ser 50: $215-224$

Keser M, Larson BR (1984) Colonization and growth of Ascophyllum nodosum (Phaeophyta) in Maine. J Phycol 20: 83-87

Keser M, Vadas RL, Larson BR (1981) Regrowth of Ascophyllum nodosum and Fucus vesiculosus under various harvesting regimes in Maine, USA. Bot Mar 24:29-38

Knight M. Parke MW (1950) A biological study of Fucus vesiculosus and Fucus serratus. J Mar Biol Assoc UK 29: 439-514

Lazo L, Markham JH, Chapman ARO (1994) Herbivory and harvesting: effects on sexual recruitment and vegetative modules of Ascophyllum nodosum. Ophelia 40:95-113

Lewis JR (1964) The ecology of rocky shores. English Universities Press, London

Lewis JR, Bowman RS (1975) Local habitat induced variations in the population dynamics of Patella vulgata (L). J Exp Mar Biol Ecol 17:165-203

Lubchenco J (1986) Relative importance of competition and predation: early colonisation by seaweeds in New England. In: Diamond JM, Case TJ (eds) Community ecology. Harper and Row, New York, p 537-555

McCook, Chapman ARO (1991) Community succession following massive ice scour on an exposed rocky shore: effects of Fucus canopy algae and of mussels during late succession. J Exp Mar Biol Ecol 154:137-169

McCook LJ, Chapman ARO (1997) Patterns and variations in natural succession following massive ice-scour of a rocky intertidal seashore. J Exp Mar Biol Ecol 214:121-147

Menge BA (1995) Indirect effects in marine rocky intertidal interaction webs: patterns and importance. Ecol Monogr $65: 21-74$

Morse ANC (1991) How do planktonic larvae know where to settle? Am Sci 79:154-167

Norton TA, Hawkins SJ, Manley NL, Williams GA, Watson DC (1990) Scraping a living: a review of littorinid grazing. Hydrobiologia 193:117-138

Oltmanns F (1889) Beiträge zur Kenntnis der Fucaceen. Bibl Bot $14: 1-94$

Printz H (1956) Recuperation and recolonisation in Ascophyllum nodosum. Proc Int Seaweed Symp 2:194-197

Printz $H$ (1959) Investigations of the failure of recuperation and repopulation on cropped Ascophyllum areas. Det Norske Videnskaps- Akademi i Oslo, I Mat-Naturv Klasse 3

Reed DC. Foster MS (1984) The effect of canopy shading on

Editorial responsibility: Otto Kinne (Editor),

Oldendorf/Luhe, Germany algal recruitment and growth in a giant kelp forest. Ecology $65: 937-948$

Robertson BC (1987) Reproductive ecology and canopy structure of Fucus spiralis L. Bot Mar 30:475-482

Santelices B, Ojeda FP (1984) Effects of canopy removal on the understorey algal community structure of coastal forests of Macrocystis pyrifera from southern South America. Mar Ecol Prog Ser 14:165-173

Sharp G (1986) Ascophyllum nodosum and its harvesting in eastern Canada. In: Caddy JF, Santilices B, Doty MS (eds) Case studies of seven commercial seaweed resources. FAO Fish Biol Tech Pap 4:3-48

Sousa WP, Schroeter SC, Gaines SD (1981) Latitudinal variation in intertidal algal community structure: the influence of grazing and vegetative propagation. Oecologia 48: $297-307$

Southward AJ (1964) Limpet grazing and the control of vegetation on the shore. In: Crisp DJ (ed) Grazing in terrestrial and marine environments. Blackwell Scientific Publications, Oxford, p 265-273

Southward AJ, Southward EC (1978) Recolonization of rocky shores in Cornwall after use of toxic dispersants to clean up the Torrey Canyon spill. J Fish Res Board Can 35:682-706

Stephenson TA, Stephenson A (1972) Life between tidemarks on rocky shores. WH Freeman and C.o, New York

Stewart JG (1982) Anchor species and epiphytes in intertidal algal turf. Pac Sci 36:45-59

Sundene $O$ (1973) Growth and reproduction in Ascophyllum nodosum (Phaeophyceae). Norw J Bot 20:249-255

Underwood AJ, Jernakoff P (1981) Effects of interactions between algae and grazing gastropods on the structure of a low-shore intertidal algal community. Oecologia 28: 221-233

Velimirov B, Griffiths CL. (1979) Wave-induced kelp movement and its importance for community structure. Bot Mar 22:169-172

Williams GA (1990) The comparative ecology of the flat periwinkles Littorina obtusata (L.) and L, mariae Sacchi et Rastellı. Field Stud 7:469-482

Worm B, Chapman ARO (1996) Interference competition among two intertidal seaweeds: Chondrus crispus strongly affects survival of Fucus evanescens recruits. Mar Ecol Prog Ser 145:297-301

Worm B, Chapman ARO (1998) Relative effects of elevated grazing pressure and competition from a red algal turf on two post-settlement stages of Fucus evanescens C. Ag. J Exp Mar Biol Ecol 220:247-268

Submitted: December 31, 1998; Accepted: June 3, 1999 Proofs received from author(s): October 15, 1999 